\title{
DETEKSI KEASLIAN UANG KERTAS BERDASARKAN WATERMARK DENGAN PENGOLAHAN CITRA DIGITAL
}

\author{
Agung Rilo Pambudi ${ }^{1}$, Garno $^{2}$, Purwantoro ${ }^{3}$ \\ 1,2,3 Teknik Informatika, Fakultas Ilmu Komputer, Universitas Singaperbangsa Karawang \\ ${ }^{1}$ agung.16020@ student.unsika.ac.id, ${ }^{2}$ garno@ staff.unsika.ac.id, ${ }^{3}$ purwantoro.masbro@ staff.unsika.ac.id
}

\begin{abstract}
Abstrak
Uang adalah alat bantu tukar atau standar dari pengukur nilai (kesatuan hitungan) yang sah, dikeluarkan oleh pemerintah suatu negara berupa kertas, emas, perak atau logam-logam lain yang dicetak dengan bentuk dan gambar tertentu. Deteksi adalah suatu proses untuk memeriksa atau melakukan pemeriksaan terhadap sesuatu dengan menggunakan cara dan teknik tertentu. Seiring dengan kemajuan teknologi informasi, kriminalitas yang memanfaatkan teknologi juga berkembang. Pengolahan citra digital saat ini telah berkembang kegunaannya untuk melakukan sistem pengenalan terhadap kemungkinan gangguan kriminalitas, terutama untuk pengenalan objek yang unik, watermark pada uang kertas rupiah. Dalam segmentasi citra juga terdapat beberapa metode, contohnya yaitu canny edge detection. Canny edge detection adalah metode yang menghasilkan sebuah tampilan gambar yang berbeda dengan menampilkan efek relief di dalamnya. Tujuan penelitian ini yaitu untuk mendeteksi keaslian uang kertas dengan watermark menggunakan metode canny edge detection. Proses dari penggunaan metode diatas dengan cara akuisisi citra, operasi grayscale, operasi morfologi, kemudian canny edge detection. Citra yang digunakan dalam penelitian ini berjumlah 21 citra yang terdiri dari nominal uang kertas 1.000, 2.000, 5.000, $10.000,20.000,50.000$, dan 100.000. Hasil terakhir dari proses canny edge detection adalah kumpulan piksel yang digunakan untuk menentukan apakah di citra tersebut memiliki watermark atau tidak. Dari penelitian tersebut hasil dari akurasi program deteksi watermark pada uang kertas menggunakan metode canny edge detection untuk mendeteksi keaslian uang yaitu sebesar $85,71 \%$.
\end{abstract}

Kata kunci : canny, deteksi, pengolahan citra, uang, watermark,

\section{Pendahuluan}

Perkembangan teknologi informasi semakin maju dan berkembang setiap saat dengan cepat Riad et al (2018). Perkembangan ini juga terjadi pada teknologi di bidang informatika. Hal ini terjadi di segala aspek kehidupan sehari - hari. Dikatakan dalam jurnalnya Agus dan Riskawati, 2016, bahwa teknologi informasi saat ini menjadi pedang bermata dua karena selain memberikan kontribusi bagi peningkatan kesejahteraan, kemajuan dan peradaban manusia, sekaligus menjadi sarana efektif perbuatan melawan hukum. Seiring dengan kemajuan teknologi informasi, kriminalitas yang memanfaatkan teknologi juga berkembang. Menurut Dewi et al (2018), kriminalitas merupakan tindakan yang melanggar aturan undang-undang yang dapat meresahkan masyarakat.

Peredaran uang palsu dari tahun ke tahun terus terjadi kenaikan. Kenaikan ini dikarenakan mudahnya memperoleh informasi cara membuat uang palsu di internet dan perkembangan teknologi pada saat ini, terlebih lagi dengan perkembangan teknologi printer berwarna yang bahkan mempermudah para pelaku tindak kejahatan pemalsuan uang (Sani et al, 2016).
Salah satu perkembangan teknologi informasi adalah image processing. Image processing atau biasa disebut pengolahan citra digital. Pengolahan citra digital merupakan teknik mengolah citra yang bertujuan memperbaiki kualitas citra agar mudah diinterpretasi oleh manusia atau mesin komputer yang dapat berupa foto maupun gambar bergerak Effendi et al, (2017). Salah satu ciri untuk menentukan uang asli dengan mendeteksi ada tidaknya watermark pada uang kertas tersrbut. Untuk itu, perlu adanya suatu teknologi yang dapat mengetahui dan mendeteksi watermark pada uang kertas.

Pada penelitian serupa yaitu Aplikasi Pendeteksi Tanda Air pada Uang Kertas dengan Metode Segmentasi Region Based Active Contour Menggunakan Matlab. Pada penelitian ini pendeteksian watermark dilakukan dengan metode region based active contour dimana citra yang digunakan hanya hanya ada dua jenis nominal mata uang dengan tahun emisi yang lama dan jumlah citra yang diuji berjumlah 6 buah yang bisa dikatakan membuat tingkat akurasinya menjadi bias. Fadli \& Karyati (2016)

Pada penelitian sebelumnya (Dianta, 2016) Deteksi Tepi Menggunakan Metode Canny Dengan 
Matlab Untuk Membedakan Uang Asli dan Uang Palsu. Pada penelitian ini menggunakan pengukuran jarak Eclidean, nilai Dissimilaritas dan Similaritas. Tetapi hasil dari pengujian tingkat akurasi sistemnya tidak ada dan skenario uji yang tidak lengkap.

Deteksi tepi (edge detection) pada suatu citra adalah proses yang membentuk tepi-tepi pada objekobjek gambar atau citra. Pada penelitian sebelumnya deteksi tepi canny lebih baik dari deteksi tepi sobel, dan deteksi tepi prewitt dikarenakan dengan deteksi tepi canny garis tepi suatu citra terlihat jelas (Sukatmi, 2017).

Deteksi tepi canny diunggulkan dalam membentuk tepi citra yang jelas, tetapi setiap jenis metode deteksi tepi memiliki kelebihan dan kekurangan seperti halnya deteksi tepi metode sobel yang memiliki kemampuan dapat mengurangi noise sebelum melakukan perhitungan deteksi tepi (Sukatmi, 2017) dan menurut (Dianta, 2016) metode sobel adalah metode yang banyak digunakan sebagai pendeteksi tepi karena kesederhanaan dan keampuhannya.

Dilihat dari latar belakang diatas peneliti bermaksud ingin mengetahui penerapan pengolahan citra digital untuk mendeteksi keaslian uang kertas berdasarkan watermark menggunakan metode canny edge detection

\section{Landasan Teori}

\subsection{Uang}

Pengertian uang menurut KBBI (Kamus Besar Bahasa Indonesia) adalah alat bantu tukar atau standar dari pengukur nilai (kesatuan hitungan) yang sah, dikeluarkan oleh pemerintah suatu negara berupa kertas, emas, perak atau logam-logam lain yang dicetak dengan bentuk dan gambar tertentu. Hampir seluruh kegiatan ekonomi menggunakan alat pembayaran ini. Oleh karena itu, keberadaan uang dalam kegiatan sehari - hari begitu penting untuk memenuhi kebutuhan seperti memperoleh jasa, barang, dan kebutuhan hidup lainnya. Terdapat beberapa jenis uang yaitu uang barang uang kertas, uang kredit, dan giro (Sari, 2016).

Uang rupiah mempunyai ciri-ciri berupa tandatanda tertentu yang bertujuan mengamankan uang rupiah dari adanya pemalsuan. Seperti yang dikutip dari data Bank Indonesia, Dalam menetapkan ciri-ciri uang dianut suatu prinsip bahwa semakin besar nilai nominal uang maka semakin banyak unsur pengaman (Secutiy Features) dari uang tersebut.

Secara umum, tanda-tanda keaslian uang rupiah dapat dikenali dari unsur pengaman yang terdapat pada bahan uang dan teknik cetak yang digunakan, yaitu:

1. Tanda air (Watermark)
Pada uang kertas terdapat tanda air berupa gambar yang dapat terlihat jika diterawang ke arah cahaya.

2. Benang pengaman (Security Thread)

Ditanam pada tengah kertas atau terlihat seperti dianyam hingga tampak sebagai garis lurus yang vertical atau dari atas ke bawah, bisa dibuat memendar di bawah sinar matahari (ultraviolet) dengan satu atau beberapa warna.

3. Gambar saling isi (rectoverso)

Pencetakan suatu bentuk yang menghasilkan cetakan pada bagian depan dan belakang berada tepat dan saling mengisi jika diterawang ke cahaya matahari.

4. Tulisan Mikro (Micro Text)

Tulisan berukuran mini yang hanya dapat dibaca dengan menggunakan kaca pembesar.

5. Tinta Berubah Warna (Optical Variable Ink)

Hasil cetak mengkilap dan berubah-ubah warnanya apabila dilihat dari sudut pandang yang berbeda.

6. Tinta Tidak Tampak (Invisible Ink)

Hasil cetak tidak terlihat yang akan memendar di bawah sinar ultraviolet.

7. Gambar Tersembunyi (Latent Image)

Teknik cetak dimana di dalamnya terdapat tulisan tersembunyi yang bisa dilihat dari sudut pandang tertentu.

8. Cetak Intaglio

Cetakan yang jika diraba akan terasa kasar.

$$
R(x, y)= \begin{cases}1 & \text { jika } f(x, y)>=T \\ 0 & \text { sebaliknya }\end{cases}
$$

\subsection{Pengolahan Citra}

Menurut Muwardi \& Fadlil (2018) Pengolahan citra merupakan bidang yang bersifat multi disiplin, yang terdiri dari banyak aspek, antara lain: fisika (optik, nuklir, gelombang, dll), elektronika, matematika, seni, fotografi, dan teknologi komputer.

Pengolahan citra (image processing) mempunyai keterikatan yang erat dengan disiplin ilmu yang jika sebuah disiplin ilmu dinyatakan dalam bentuk proses suatu input menjadikan output, maka pengolahan citra memiliki input berpupa citra serta output berupa citra.

\subsection{Akuisisi Citra}

Akuisisi data adalah langkah dalam mendapatkan citra. Tujuan dari langkah ini adalah untuk menentukan data yang dibutuhkan dan memilih metode perekaman citra digital. Langkah-langkah yang dilakukan dalam ini secara umum dimulai dari persiapan obyek yang akan diambil citranya, alat-alat, sampai pada pencitraan (Kusumadewa \& Supatman, 2018). 


\subsection{Segmentasi Citra}

Segmentasi citra adalah proses pengolahan citra yang bertujuan memisahkan wilayah (region) objek dengan wilayah latar belakang agar objek mudah dianalisis dalam rangka mengenali objek yang banyak melibatkan persepsi visual. (Sinaga, 2017)

Proses segmentasi citra didasarkan pada perbedaan derajat keabuan citra. Untuk mengubah citra berwarna yang mempunyai nilai matrik masingmasing $\mathrm{r}$, g dan b menjadi citra grayscale dengan nilai $\mathrm{s}$, maka dilakukan konversi dengan mengambil ratarata dari nilai $r$, g dan $b$.

$$
S=\frac{r+g+b}{3}
$$

\subsection{Thresholding}

Thresholding berfungsi sebagai pengatur jumlah derajat keabuan yang ada pada citra (Sinaga, 2017). Menurut Nurhayati, Afifah, \& Rustanti (2018) operasi thresholding berfungsi sebagai pengubah citra dengan pola skala keabuan, yang mempunyai kemungkinan nilai lebih dari 2, ke citra biner yang memiliki 2 nilai (0 dan 1). Proses binersisasi citra grayscale untuk menghasilkan citra biner :

$$
g(x, y)=\left\{\begin{array}{l}
1 \text { if }(x, y) \geq T \\
0 \text { if }(x, y) \leq T
\end{array}\right.
$$

\subsection{Deteksi Tepi}

Menurut Romindo dan Khairina (2017) deteksi tepi yaitu suatu proses yang berfungsi untuk menentukan lokasi titik-titik yang merupakan tepi pada obyek. Deteksi tepi menggunakan operasi yang dijalankan untuk mendeteksi garis tepi (edges) yang membatasi dua wilayah citra homogen yang memiliki tingkat kecerahan yang berbeda. Mencirikan batas objek dan berguna untuk proses segmentasi dan identifikasi objek adalah salah satu tujuan deteksi tepi.

Untuk mendeteksi tepi-tepi pada citra dapat menggunakan metode Sobel, Prewitt, Robert, Laplacian of a Gaussian, Canny, dan lain-lain.

\subsection{MATLAB}

Matlab merupakan bahasa pemrograman yang digunakan pada teknik seperti penyelesaian matematik dan metode numerik, MATLAB menyediakan fasilitas untuk komputasi, visualisasi, pemrograman dan pengolahan database. Selain itu MATLAB memiliki fitur yang dikelompokan berdasarkan aplikasi tertentu yang dikenal dengan nama tool box. Dengan tool box ini pengguna diharapkan dapat mempelajari dan mengaplikasikan teknologi pada bidang kajian tertentu (Kodong, 2015).

\section{Cara Pengujian}

\subsection{Objek Penelitian}

Objek pada penelitian ini adalah uang kertas rupiah asli, dengan nilai nominal uang kertas sebagai berikut, 1.000, 2.000, 5.000, 10.000, 20.000, 50.000, dan 100.000, dengan kondisi uang kertas yang baik tidak terlipat dan tidak ada coretan. Citra yang diambil berupa tampilan uang kertas tepat di posisi tanda air berada. Yang dimana citra uang rupiah asli berjumlah 21 buah. Citra tersebut mempunyai ukuran citra 880 x 980 dengan format .png.

\subsection{Metode}

Penelitian ini menggunakan metode eksperimental. Metode eksperimental merupakan metode yang digunakan untuk mengetahui sebabakibat dari suatu kejadian

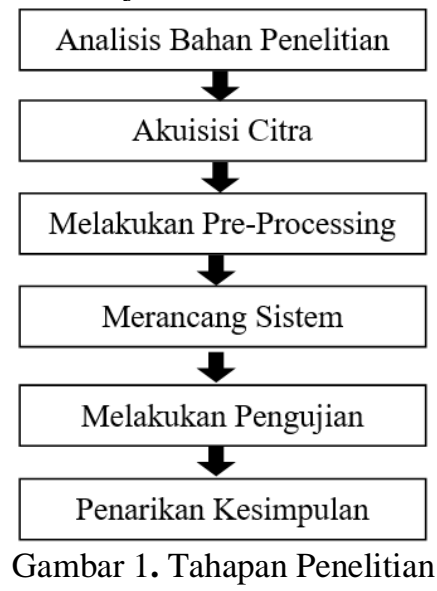

Tahapan yang terdapat dalam metode ekperimental adalah sebagai berikut: Pemilihan ide atau topik penelitian, Merumuskan masalah penelitian, merumuskan hipotesis, Menentukan variabel, Menentukan tipe dan desain penelitian, Merancang dan melaksanakan penelitian, Menganalisis hasil penelitian, dan membuat kesimpulan. Adapun dalam pelaksanaan penelitian ini mengacu pada rancangan penelitian yang dapat diliat pada Gambar 1.

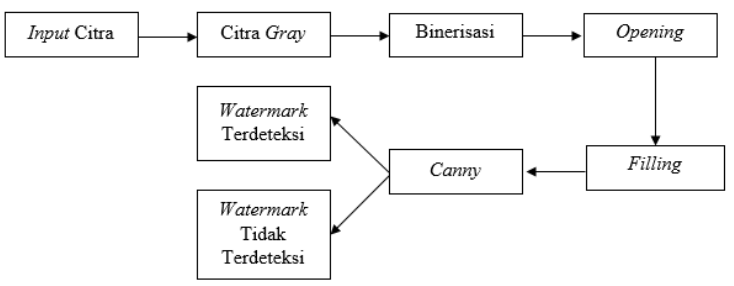

Gambar 2. Alur Penelitian 
Pada gambar di atas menggambarkan alur proses untuk melakukan deteksi menggunakan canny edge detection. Dalam sistem ini terdiri dari beberapa proses, sebelum melewati proses tersebut yang dilakukan adalah memasukkan citra uang yang sudah diakuisi setelah itu dapat melanjutkan pada opersi selanjutnya yaitu, operasi grayscale untuk mengubah menjadi citra keabuan.

\section{gray = rgb2gray $(\mathrm{I})$;}

Selanjutnya melalui operasi binerisasi untuk mengubah kedalam citra biner (1 dan 0$)$.

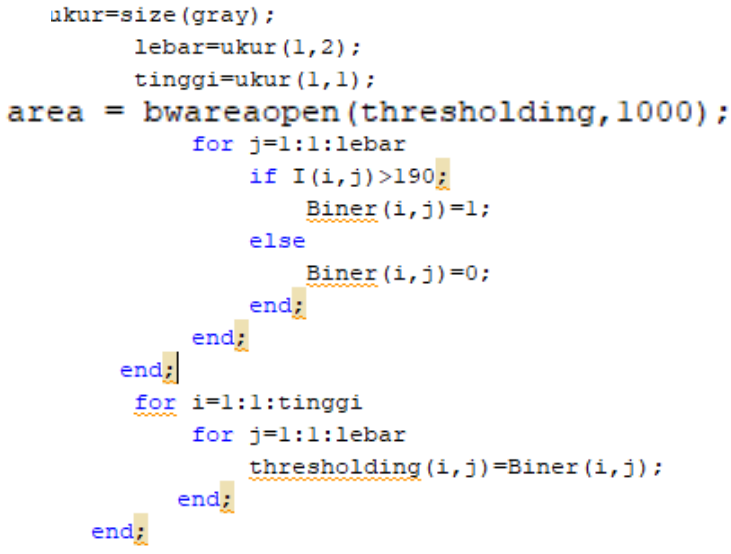

Kemudian operasi opening untuk membersihkan noise.

Selanjutnya operasi filling untuk mengisi lubang - lubang pada citra,

Img = imfill (area, 'holes");

Setelah itu operasi canny untuk membuat citra tepi.

$\mathrm{E}=$ edge (area, 'canny');

Terdapat kondisi untuk mendeteksi watermark pada uang kertas yaitu dengan mendeteksi hasil piksel.

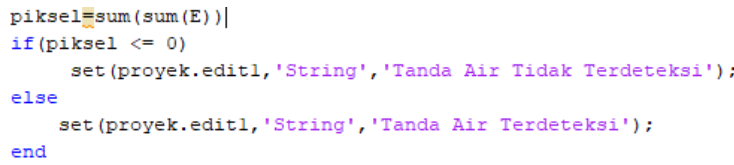

\section{Hasil Penelitian}

\subsection{Bahan Penelitian}

Pada tahap ini peneliti akan memberikan rincian bahan-bahan yang akan digunakan dalam penelitian. Penulis membutuhkan uang kertas rupiah asli untuk dijadikan citra digital, dengan nilai nominal uang kertas sebagai berikut, 1.000, 2.000, 5.000, 10.000, 20.000, 50.000, dan 100.000. dalam kondisi uang kertas yang baik tidak terlipat dan tidak ada coretan. Penelitian ini dilakukan dengan menggunakan alat berbentuk kotak untuk menjaga cahaya dari dalam dan menghindari cahaya dari luar. Alat tersebut terbuat dari kardus berbentuk persegi panjang berukuran panjang $35 \mathrm{~cm}$, lebar $29 \mathrm{~cm}$, dan tinggi 29 $\mathrm{cm}$. Di dalam kotak tersebut diberikan lampu lampu LED (Light Emitting Diode) 3 watt. Kemudian diberi tatakan untuk menyangga uang yang terbentuk dari bekas selotip. Penelitian ini akan menggunakan matlab untuk aplikasi pengolahan citra.

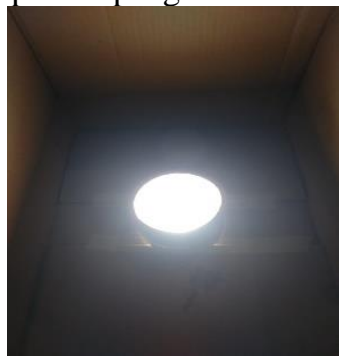

Gambar 3. Kotak Untuk Pengambilan Citra

\subsection{Akuisisi Citra}

Pada tahap ini peneliti melakukan pengambilan citra uang. Uang yang diambil citranya dengan cara menyusunnya pada sebuah tatakan diatas lampu dengan penempatan uang di atas tatakan yang telah disediakan. Data yang digunakan berupa gambar-gambar bagian uang yang terdapat watermark yang telah diambil menggunakan kamera handphone.

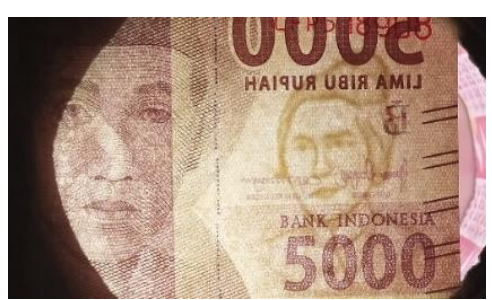

Gambar 4. Pengambilan Citra Uang di Dalam Kotak

\subsection{Pre-Processing}

Proses pre processing dilakukan untuk memperoleh citra yang selanjutnya dapat dimanfaatkan untuk sistem yang akan dibuat. Proses ini meliputi proses cropping, compressing size citra, segmentasi citra dan menutup noise pada citra. Proces cropping, compressing size citra dilakukan secara manual dengan menggunakan software pendukung photoscape. Cropping citra dilakukan dengan perbandingan 1:1 dengan size citra sebesar 820 x 980 pixel. Proses ini dilakukan menggunakan aplikasi pendukung seperti photoscape.

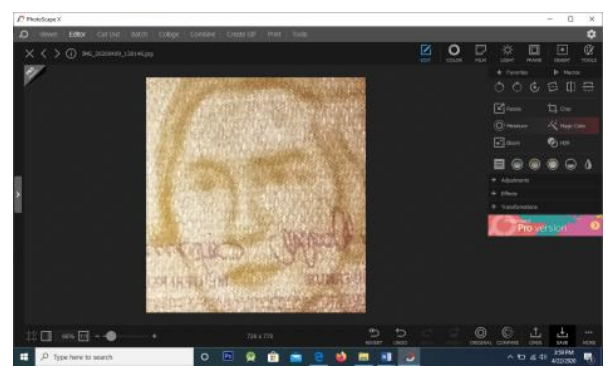

Gambar 5. Proses Cropping dan Resize Pada Photoscape 


\subsection{Perancangan Sistem}

Langkah pertama dalam membuat program deteksi tanda air adalah dengan merancang tampilan program dengan menggunakan GUI pada Matlab.

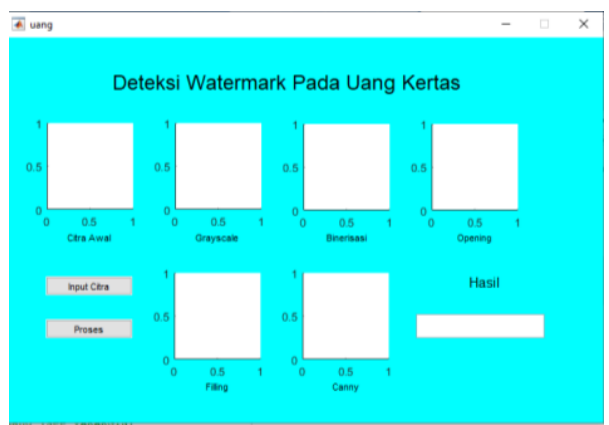

Gambar 6. Tampilan Awal Program

Setelah perancangan program dibuat dengan menggunakan GUI, dilakukan callback untuk memenuhi source code. Setelah membuat source code, maka langkah terakhir adalah dengan mencoba program tersebut.

Pada data set disediakan citra uang sebanyak 21 gambar yang terdiri dari nominal 1.000, 2.000, $5.000, \quad 10.000$, 20.000, 50.000, dan 100.000. Kemudian citra akan tampil seperti pada gambar 7 .

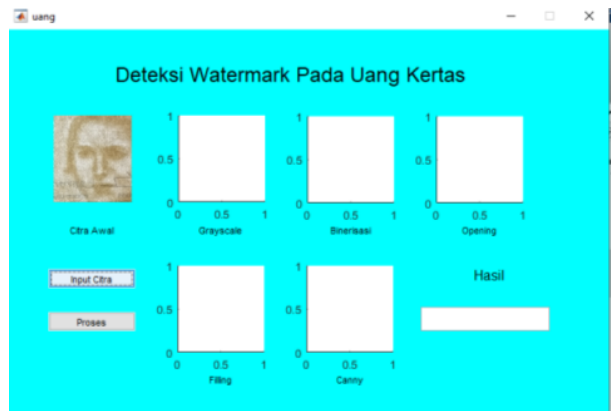

Gambar 7. Tampilan Input Citra Yang Telah Dipilih

Tombol proses berfungsi untuk menjalankan proses deteksi watermark. Inputan citra yang akan diproses terlebih dahulu tampil pada kolom citra yang berupa citra berwarna RGB (gambar 4.7).

Setelah menekan tombol proses maka akan muncul kelima tahapan proses yaitu grayscale, binerisasi, opening, canny dengan output yang akan menampilkan hasil dari deteksi watermark yang diproses pada masing-masing kolom yang tersedia sesuai dengan keterangan yang tertera pada tampilan figure. Dalam eksekusi tombol proses didapatkan juga keterangan apakah watermark pada citra uang yang diproses tedeteksi atau tidak yang berupa message text seperti pada gambar 4.7. Jika semua proses pengujian selesai dan sudah didapatkan hasilnya.

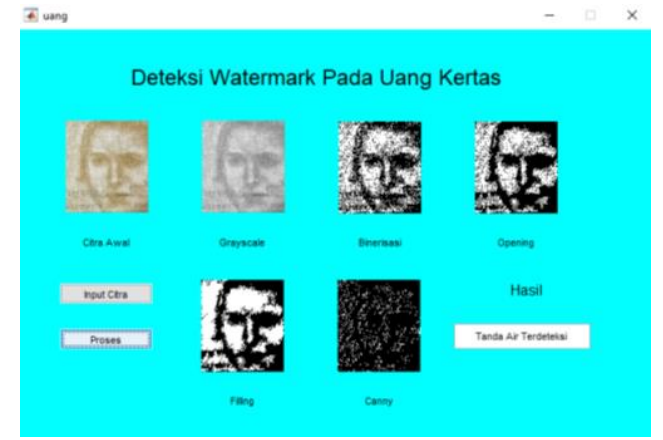

Gambar 8. Tampilan Citra Yang Telah Diproses

\subsection{Pengujian}

Berdasarkan hasil uji coba yang telah dilakukan untuk mendeteksi watermark, maka akan dilakukan analisis proses. Pada analisis proses didapatkan hasil gambar dari program, mulai dari citra input sebagai citra awalan yang akan diproses dengan pengolahan citra digital. Untuk melihat hasil dari deteksi yang dilakukan oleh program dan analisis pengujian yang dilakukan oleh program, dapat dilihat pada tabel 1 .

Tabel 1. Pengujian Deteksi Watermark dengan

\begin{tabular}{|c|c|c|c|c|}
\hline \multirow{3}{*}{$\begin{array}{c}\text { Nama } \\
\text { Folde } \\
\mathbf{r}\end{array}$} & \multicolumn{4}{|c|}{ Canny Edge Detection } \\
\hline & \multirow{2}{*}{$\begin{array}{l}\text { Jenis } \\
\text { Citra } \\
\text { (Rp) }\end{array}$} & \multirow{2}{*}{$\begin{array}{c}\text { Jumlah } \\
\text { Citra }\end{array}$} & \multicolumn{2}{|c|}{ Hasil Deteksi } \\
\hline & & & $\underset{\text { i }}{\text { Terdeteks }}$ & $\begin{array}{c}\text { Tidak } \\
\text { Terdeteks } \\
\text { i }\end{array}$ \\
\hline \multirow{7}{*}{$\begin{array}{l}\text { Citra } \\
\text { Uang }\end{array}$} & 1.000 & 3 & 3 & 0 \\
\hline & 2.000 & 3 & 3 & 0 \\
\hline & 5.000 & 3 & 3 & 0 \\
\hline & 10.000 & 3 & 3 & 0 \\
\hline & 20.000 & 3 & 0 & 3 \\
\hline & 50.000 & 3 & 3 & 0 \\
\hline & $\begin{array}{c}100.00 \\
0\end{array}$ & 3 & 3 & 0 \\
\hline & \multicolumn{2}{|c|}{$\begin{array}{c}0 \\
\text { Akurasi }\end{array}$} & \multicolumn{2}{|c|}{$85,71 \%$} \\
\hline
\end{tabular}

\subsection{Penarikan Kesimpulan}

Berdasarkan tabel 1 dapat diketahui bahwa program dapat mendeteksi watermark dengan baik sehingga akurasi yang didapat adalah $85,71 \%$, akan tetapi hasil dari deteksi tepinya masih kurang maksimal dikarenakan penempatan watermark yang saling tumpang tindih dengan tanda tangan dan gambar yang lain, serta pencahayaan yang terlalu terang, dan juga diakibatkan oleh perbedaan tekstur pada setiap nominal uang kertas yang diuji.

\section{Kesimpulan dan Saran}

\subsection{Kesimpulan}

Berdasarkan hasil penelitian yang telah dilaksanakan maka didapatkan kesimpulan sebagai berikut:

1. Untuk membedakan keaslian uang kertas berdasarkan citra watermark dengan 
pendekatan komputasional pengolahan citra digital yaitu melalui proses, akuisisi citra, preprocesing, morfologi, dan langkah terakhir dengan menenteukan ada atau tidaknya pixel pada citra untuk menentukan ada atau tidaknya tanda air dengan deteksi tepi canny.

2. Dapat dilihat pada Tabel $\mathbf{4 . 3}$ hasi evaluasi dari deteksi dari keaslian uang kertas tersebut mencapai $85,71 \%$ tingkat keberhasilannya.

\subsection{Saran}

Untuk pengembangan penelitian kedepan, terdapat beberapa saran dari penulis, diantaranya:

1. Penelitian dapat dikembangkan dengan citra uji yang diambil secara langsung dari hasil capture kamera webcam.

2. Penelitian dapat dikembangkan dengan skenario pengujian yang berbeda.

3. Penelitian dapat dilakukan dengan menggunakan metode lain untuk mencari watermark.

\section{Daftar Pustaka:}

Agus, A. A., \& Riskawati. (2016). PENANGANAN KASUS CYBER CRIME DI KOTA

MAKASSAR ( Studi Pada Kantor Kepolisian Resort Kota Besar Makassar ). Jurnal Supremasi, 11(1), 20-29.

Dewi, S. N., Cholissodin, I., \& Santoso, E. (2018). Prediksi Jumlah Kriminalitas Menggunakan Metode Extreme Learning Machine ( Studi Kasus Di Kabupaten Probolinggo ). Jurnal Pengembangan Teknologi Informasi Dan Ilmu Komputer (J-PTIIK) Universitas Brawijaya, 2(11), 4687-4693.

Dianta, E. G. (2016). Deteksi Tepi Menggunakan Metode Canny Dengan Matlab Untuk Membedakan Uang Asli dan Uang Palsu. Jurnal Jurusan Teknik Informatika, Fakultas Teknologi, Industri Universitas Gunadarma, 1(1), 1-13.

Effendi, M., Fitriyah, F., \& Effendi, U. (2017). Identifikasi Jenis dan Mutu Teh Menggunakan Pengolahan Citra Digital dengan Metode Jaringan Syaraf Tiruan. Jurnal Teknotan, 11(2), 67. https://doi.org/10.24198/jt.vol11n2.7

Fadli, M. Z., \& Karyati, C. M. (2016). Aplikasi Pendeteksi Tanda Air pada Uang Kertas dengan Metode Segmentasi Region Based Active Contour Menggunakan Matlab. Jurnal Ilmiah Informatika Komputer Universitas Gunadarma, 21(3), 53-61.
Kodong, F. R. (2015). Aplikasi Autoreply Sms Menggunakan Pemrograman Matlab. Telematika, 12(1), 68-73. https://doi.org/10.31315/telematika.v12i1.626

Kusumadewa, C. C., \& Supatman. (2018). Identifikasi Citra Daun Teh Menggunakan Metode Histogram untuk Deteksi Dini Serangan Awal Hama Empoasca Leaf Image Identification Using Histogram Methods for Early Detection of Empoasca Pests Initial Attack ( a ) ( b ). Jurnal Multimedia \& Artificial Intelligence, 2(1), 27-36.

Muwardi, F., \& Fadlil, A. (2018). Sistem Pengenalan Bunga Berbasis Pengolahan Citra dan Pengklasifikasi Jarak. Jurnal Ilmiah Teknik Elektro Komputer Dan Informatika, 3(2), 124. https://doi.org/10.26555/jiteki.v3i2.7470

Nurhayati, O. D., Afifah, D. N., . N., \& Rustanti, N. (2018). Segmentasi Thresholding untuk Pemilihan Kualitas Telur Asin. Jurnal Sistem Informasi Bisnis, 8(1), 42. https://doi.org/10.21456/vol8iss1pp42-48

Riadi, I., Umar, R., \& Nasrulloh, I. M. (2018). Analisis Forensik Digital Pada Frozen Solid State Drive Dengan Metode National Institute of Justice (Nij). ELINVO (Electronics, Informatics, and Vocational Education), 3(1), 70-82. https://doi.org/10.21831/elinvo.v3i1.19308

Romindo, \& Khairina, N. (2017). Analisa Perbandingan Metode Edge Detection. Seminar Nasional Teknologi Informatika, 244-251.

Sani, K., Wahyu Winarno, W., \& Fauziati, S. (2016). Analisis Perbandingan Algoritma Classification Untuk Authentication Uang Kertas (Studi Kasus: Banknote Authentication). Jurnal Informatika, 10(1), 1130-1139. https://doi.org/10.26555/jifo.v10i1.a3344

Sari, S. W. (2016). Perkembangan Dan Pemikiran Uang Dari Masa Ke Masa. An-Nisbah: Jurnal Ekonomi Syariah, 3(1). https://doi.org/10.21274/an.2016.3.1.39-58

Sinaga, A. S. R. (2017). Implementasi Teknik Thresholding pada Segmentasi Citra Digital. Mantik Penusa, 1(2), 49.

Sukatmi, S. (2017). Perbandingan Deteksi Tepi Citra Digital dengan Menggunakan Metode Prewitt, Sobel dan Canny. KOPERTIP : Jurnal Ilmiah Manajemen Informatika Dan Komputer, 1(1), 1-4. https://doi.org/10.32485/kopertip.vli1.3 